\title{
Critical Planning Processes in Construction Projects
}

Zwikael, O. (2009). Critical planning process in construction projects. Construction Innovation, 9 (4), 372-387.

\section{Structured abstract}

\section{$\underline{\text { Purpose }}$}

The purpose of this paper is to improve construction project planning capabilities. As project management is a core capability in the construction industry, high quality project planning processes are necessary for project success.

\section{Methodology}

This study involves data collected from 555 project managers across four industries across three different countries. Project planning capabilities of construction project managers have been compared with other industrial sectors. In addition, critical project planning processes for the construction industry have been identified.

\section{Findings}

It has been found that, relative to other industrial sectors, organizations belonging to the construction sector obtain high quality of project planning and the highest success rate. In comparison with other sectors, schedule, quality, and procurement planning are most frequently executed in construction projects. Finally, the impact of the different planning processes on project success has also been investigated. The processes that have the greatest impact on project success in the construction sector are "activity definition" and "project plan development". However, it has been also 
found that construction project managers do not always invest enough effort in these critical planning processes.

Practical implications

Construction project managers, wishing to improve project performance at the planning phase of a project, should concentrate more on the accurate identification of all project activities and on the development of a high quality project plan, which can be approved by key stakeholders.

\section{Value of paper}

This paper identifies the most critical planning processes in construction projects.

This represents new knowledge for the construction management body of knowledge. 


\section{Introduction}

A major part of activities performed in construction organizations deals with planning, executing, coordinating, and controlling projects, e.g. building new structures (Blyth et al., 2004). Unfortunately, many construction projects do not meet their targets due to poor quality of management practices (Brown et al., 2001; World Bank, 1996). Therefore, the motivation for this paper is the need for project success improvement in the construction sector. In particular, this study focuses on the planning phase of a project, because of its high importance in determining project success (e.g. Kerzner, 2006; Zwikael et al., 2005; Turner, 1999).

Although some project management practices differ across application areas and sectors, many other project management processes are generic for all projects. For example, all projects involve aspects of scoping, scheduling, budgeting, and quality management (PMI, 2004). Therefore, it is possible to compare project management capabilities in the construction sector with other industries, using a generic project management methodology.

The objectives of this study are (1) to compare the relative use of project planning processes between construction organizations and other industrial sectors, and (2) to identify the most critical planning processes, which have the highest influence on project success in the construction sector. Hence, the focus of this paper is on the improvement of planning in construction projects.

This study can contribute to the construction project management body of knowledge by benchmarking with other sectors and by identifying the most important project planning processes in the construction industry. In addition, construction project managers will be able to concentrate on executing planning processes that have the highest added value on project results. The structure of this paper includes 
research methodology and design, results, and discussion, following a review of the relevant literature.

\section{Literature review}

This section introduces the recent literature from the areas of project management, the uniqueness of construction projects, and project planning.

\section{Project management}

A project is a temporary endeavor undertaken to create a unique product or service (Project Management Institute, 2004). The three main most important project characteristics include uniqueness, temporary, and predefined goals (Kerzner, 2006; Meredith and Mantel, 2006). The Project Management Body of Knowledge (PMBOK® Guide) identifies 44 processes that should be performed by a project manager during the project's life cycle (PMI, 2004). These processes are grouped in the following five processes groups: (1) Initiation is the phase of formally authorizing a new project. This phase links the project to the ongoing work of the performing organization. Projects are typically authorized as a result of one or more of the following: a market demand, a business need, a customer request, a technology advance or a social need. (2) Planning processes define and refine objectives and select the best of the alternative courses of action to attain the objectives that the project was undertaken to address. Planning is of major importance to a project because the project involves doing something that has not been done before. (3) Executing processes coordinate people and other resources, such as equipment and material, to carry out the plan in order to perform the project. (4) Monitoring and controlling processes ensure the high quality achievements of the project plan and 
updating it when necessary. (5) Closing processes formalize acceptance of the project by its customers and other stakeholders and bring it to an orderly end.

\section{Construction project management}

Construction projects usually include the design and build of a new structure. Together with the generic project management approach described above, unique methodologies for construction projects are introduced in the literature. For example, Sarshar et al. (2004) introduce SPICE (Structure Process Improvement for Construction Enterprises), which is a project process improvement framework for construction organizations. Belle (2002) introduces the 'Design-build project management' approach, which includes a new relationship between the owner and the builder.

Unique characteristics of construction projects include high dependency on consultants (e.g. Brown, 1996), high importance to trust building (Malik et al., 2007), and frequent involvement of third parties. Because of the latter, procurement methods are well developed in the construction sector. For example, different forms of procurement, such as outsourcing, privatization, and build-operate-transfer, have been developed for the construction sector in the UK (Mustafa, 1999). The PMBOK (PMI, 2004) identifies procurement as one of the nine main project knowledge areas and suggest several other procurement management processes. These processes include procurement planning, solicitation planning, solicitation, source selection, contract administration, and contract closeout.

Another uniqueness of construction projects involves two specific positions which are not found in other sectors. These positions include project planners and estimators. Construction project planners add value to the contracting organization by 
ensuring that estimating and tendering are based on a robust understanding of the methods, time and space required to carry out the tasks for each building contract and the corresponding risks involved (Graham and Kelsey, 2005). In recent years, the number of experienced planners has been decreased (Heesom and Mahdjoubi, 2004). The second unique position in the construction industry is the "estimator". The estimator's main task is to predict the likely costs (Leung et al., 2005) or resources (Tam and Tong, 2005) involved in executing a future project. As project managers, project planners, and estimators are all involved in project planning, the content of this paper is highly relevant to them as well to senior management in construction organizations.

Construction project success is usually measured by four typical success measures including cost, schedule, quality of performance, and safety (Hughes et al., 2004). Robinson et al. (2005) suggest a performance measurement system for projects in construction engineering organizations. Project success analysis in the construction sector is vastly reported in the literature. For example, a large-scale World Bank study of construction projects (1996) has found that of the 900 surveyed projects, an average cost overrun of $40 \%$ over the original cost and an average time overrun of $60 \%$ over the planned completion time were reported. Leung et al. (2004) have found that even in a sample of successful construction project cost and schedule overruns have been found. The major reasons for the failure in many construction projects include: (1) lack of integration that may exist between designers and builders; (2) the use of innovative materials; (3) the use of incorrect procurement systems; (4) the condition of the general contracting market, and (5) the inherent "uniqueness" of each new building project (Brown et al., 2001). 
Despite these poor results, studies have found that construction organizations have higher maturity levels and capabilities of performing project processes than organizations in other industrial sectors (e.g. Pennypacker and Grant, 2003; Ibbs and Kwak, 2000). These results are mainly attributed to leadership, information sharing, and degree of authorization (Cooke-Davies and Arzymanow, 2002).

In order to support construction project managers in focusing on the most important managerial processes, several studies have tried to identify the critical factors for construction project success. Petersen and Murphree (2004) have found that owner representatives have a positive impact on balancing project constraints, such as time, cost, quality, and scope in a design-build construction environment. They further asserted that managerial skills are the most important for owner representatives on design-build projects. They illustrated the importance of soft skills for project integrators, as they execute owner representative duties in a construction environment. Kadefors (2005) has found that formal system for keeping records of project communication and decision-making to be very useful in construction projects. In addition, competitive bidding has been found to be the common method of concessionaire selection in many large projects (Chen and Messner, 2005). The adoption of competitive tendering has improved transparency, fairness, and allocation of resources and expertise. This has allowed bidders to focus on cost and technical factors rather than time-consuming negotiations and political matters (Silk and Black, 1999). Wood and Ellis (2005) identified partnering relationships as a successful procurement method, based on their experience in UK construction projects. 


\section{Project planning}

The literature suggests that project planning has significant impact on project success (Pinto and Slevin, 1989; Johnson et al., 2001; Turner, 1999; Globerson and Zwikael, 2002; Zwikael and Sadeh, 2007). Project planning is defined as the establishment of a set of directions in sufficient detail to tell the project team exactly what must be done, when it must be done and what resources to use in order to produce the deliverables of the project successfully (Meredith and Mantel, 2006). Responsibility for planning lies entirely with the project manager, who must ensure that the project is carried out properly to the complete satisfaction of all relevant stakeholders. Major advantages of proper project planning are: (1) to eliminate or reduce uncertainty, (2) to improve efficiency of the operation, (3) to obtain a better understanding of project objectives, and (4) to provide a basis for monitoring and controlling work (Kerzner, 2006).

The major outcome of the planning phase is the project plan. This document is developed by the project team during the planning phase of the project. The project plan contains the following elements: overview, project objectives, general approach, contractual aspects, schedules, resources, personnel, risk management plan and evaluation methods (Meredith and Mantel, 2006). In order to develop a project plan, several managerial processes should be executed. Possible lists of planning processes can be found in different sources. For example, Russell and Taylor (2003) identified seven planning processes, which include defining project objectives, identifying activities, establishing precedence relationships, making time estimates, determining project completion time, comparing project schedule objectives and determining resource requirements to meet objectives. Kerzner (2006) identifies nine major components of the planning phase: objective, program, schedule, budget, forecast, 
organization, policy, procedure and standard. The PMBOK, which lists 44 processes, identified 21 as planning processes (PMI, 2004).

Although the relevant planning processes have been recognized, research has not yet clearly identified which of these are more crucial. As a result, project managers and planners, who are short of time and, therefore, unable to properly perform all planning processes. As a result, they may choose to perform the easiest planning processes, or those mandatory to the start of a project, rather than the ones that contribute the most to the success of the project. Zwikael and Globerson (2006) identified the following six planning processes as the ones that highly contribute to project success: "definition of activities to be performed in the project", "schedule development", “organizational planning", "staff acquisition", "communications planning" and "developing a project plan". However, this paper was not focused on construction projects, as its results are based on responses mainly from the Information Technology sector. Hence, its conclusions can hardly extend the knowledge on construction projects (e.g. Pinto and Slevin, 1989; Ibbs and Kwak, 2000; Shenhar et al., 2005). This paper will use the same approach, but will identify unique critical planning processes for construction projects.

There are also indications that environmental factors may impact the identification of critical project processes. For example, Crawford et al. (2006) have found variation in project management knowledge and practices among industries, countries, and application areas. Faniran et al. (1998) have found three critical success factors influencing construction project planning, including: (1) investing enough planning time before work on-site, (2) reduce emphasis on developing schedules for monitoring and controlling of project progress, and (3) increase emphasis on developing operational plans for project implementation. 
This study uses the Project Management Planning Quality (PMPQ) model, which was introduced by Zwikael and Globerson (2004). The reasons for adopting this model in the current study are: (1) it is based on an acceptable project management body of knowledge; (2) it is a generic model and hence can be used to compare construction projects with others; (3) it focuses on project planning; (4) it was found to be reliable, and (5) it is easy to use.

This model has been used in this study as a vehicle to compare projects in different industries, to identify the relative use of project planning processes by project managers, and to identify critical planning processes for construction projects. The next section describes the model, the questionnaire, and the data collection process.

\section{Research design}

The PMPQ model evaluates the overall extent of use of project planning processes. It is based on the processes to be performed by a project manager during the planning phase of a project. The model analyzes project planning processes as defined in the PMBOK (PMI, 2004). The PMBOK has been chosen as the main body of knowledge for the PMPQ model from the following reasons: (1) The PMBOK is recognized as a standard by the American National Standard Institute (ANSI). (2) The PMBOK is continuously being updated by project management practitioners. (3) The PMBOK is used by many large organizations all around the world. (4) Many studies have used this body of knowledge; hence, results from a research, which is based on the PMBOK, are easy to compare with previous studies. 
The sixteen planning processes used in this study have been adopted from the PMBOK (PMI, 2000), and are described in Figure 1. The four project success measures are the common ones used in project environment namely, schedule overrun, cost overrun, project performance, and customer satisfaction (e.g. Zwikael and Globerson, 2006; Kerzner, 2006; Zwikael, 2008). In aligned with the research objectives, the research model, which is presented in Figure 1, aims at investigating the influence of sixteen project planning processes on four project success dimensions in the construction sector, in order to find the planning processes which have the most significant impact on project success.

\section{$<$ Figure $1>$}

\section{Questionnaire design}

Based on the research model, a questionnaire was developed, as shown in details in Appendix A. A quantitative approach was selected to allow objective comparison across different industries. The objective of this questionnaire was to collect data regarding managerial processes executed in projects and the success of these projects. In the questionnaires, project managers were asked to estimate the frequency of use of project planning practices (using a 1-5 Likert scale) in the most recent completed projects they had managed. This scale was been chosen to be constant with other maturity models developed for a similar purposes (e.g. Paulk et $a l ., 1995$; Ibbs and Kwak, 2000). In order for the project managers to make accurate estimates, the relevant planning processes and tools have been introduced and demonstrated. 
While the independent variables - planning processes - were collected from project managers, the dependent variables were collected from their supervisors to avoid 'same source bias'. Supervisors were requested to evaluate the following four project success dimensions: cost overrun and schedule overrun, measured in percentages from the original plan. Cost overrun and schedule overrun have been measured in percentages, calculating the ratio of the actual-planned values difference and the planned value. For example, a positive number refers to an overrun, while a negative value indicates that the project was completed ahead of time or below the planned budget. These values exclude legitimate variations imposed by the customer. Project performance and customer satisfaction have been measured on a scale of one to ten, where "1" represents low project performance and low customer satisfaction, and "10" represents high project performance and high customer satisfaction. The selection of a 1-10 scale for these success measures is meant to allow wide range of responses, while project success is evaluated.

\section{Data collection}

The questionnaire was administered to 753 project managers in three countries from different regions - Israel, Japan, and New Zealand. Initial data collection involved project managers who are members in the Project Management Institute (PMI), which supported this study in each of these countries. Yet, recognizing the danger of this type of data collection as a sole source, the other half of questionnaires was collected from organizations selected and personally visited by the research team. For that reason, the research team assembled organization names from a variety of local sources, to make sure research sample includes organizations from different 
sizes, all relevant industry sectors, and with different levels of project risk. The two groups were compared to make sure that they both led to similar conclusions.

Industries constituted this study included construction, services (e.g. banks and tourism), information technology (e.g. software), and production and maintenance (e.g. the food industry). In order to increase the reliability of data collected, only questionnaires that had at least $80 \%$ completed data were included in the final data analysis (for example, refer to Zwikael and Globerson, 2004). Using this criterion, 555 questionnaires remained for the final analysis, including 115 from the construction industry. This represents a return rate of $74 \%$, which has been achieved mainly due to the high involvement of PMI in all these countries. Table 1 identifies on the distribution of data among industries. It includes the number of questionnaires sent to project managers from each industry, the number of valid returned questionnaires, and the percentage of valid returned questionnaires in each industry. The distribution of valid questionnaires among the three countries is also presented in Table 1.

\section{$<$ Table $1>$}

\section{Validity and reliability}

The reliability of this model was calculated using two statistical tests. First, Cronbach's Alpha value was calculated, and its value (0.91) was considerably higher than the minimum value required by the statistical literature (Garmezy et al. 1967; Hair, 2006). Another reliability test involved the administration of the same questionnaire to one pair of a project manager and his direct supervisor; both have been asked to fill in the questionnaire with the same project in mind. Similar results 
have been found in both questionnaires, which demonstrate that the questionnaire can be clearly understood.

The model's validity has been evaluated by comparing the overall Project Planning Index (PPI) with the project success. The PPI index has been calculated from the questionnaires as the average of all 16 planning items. This index represents the overall extent of use of planning processes on a scale of one to five. It has been found that the overall PPI is highly correlated with the perception of project success, as measured by schedule overrun, cost overrun, project performance, and customer satisfaction. A summary of the analysis is presented in Table 2. All results are highly significant with p-values under .01, which is considered to be the best desired statistic significant level.

\section{$<$ Table 2 >}

Table 2 shows that the PPI is significantly correlated with each of the project's results. This means that the more effort is invested by project managers in the planning processes, the better project results are. For example, improvement in planning reduces schedule overrun by $10 \%$ for each PPI unit. For poor level of planning (PPI=1), the average schedule overrun is $43 \%$, where for best level of planning (PPI=5), the expected schedule overrun is only $3 \%$. One conclusion from the above statistical analysis is that the model is reliable and valid and can be used to evaluate the extent of use of project planning. 


\section{Results and discussion}

This section includes the analysis of the results, focused on the study objectives, i.e. comparing construction projects to other sectors and identifying critical planning processes for construction projects. First, a comparison of project success among the industries is presented.

\section{Project success analysis}

This section presents project success comparison between the construction and other sectors. Results in Table 3 present the differences in project success among the four industries, according to each project success measure.

\section{$<$ Table 3 >}

Table 3 presents the average project success for the four industries, measured according to the four success measures. It has been found that in all four project success measures, construction organizations have better results than in any other industry. These results are aligned with previous findings in the literature emphasizing the high maturity levels and project management capabilities in the construction sector (e.g. Pennypacker and Grant, 2003; Ibbs and Kwak, 2000).

\section{Cross-industry planning processes analysis}

This section compares the extent of use of planning processes among industries. The actual use of each planning process has been calculated for each of the four industries: (1) construction, (2) software and communications, (3) services, and (4) production and maintenance. In addition, the PPI index, which presents the overall 
use of the 16 planning processes included in the model, has been calculated for each of the four sectors. The results are presented in Table 4 .

\section{< Table 4 >}

Construction organizations which scored high on project success, obtained the highest PPI score (3.8), second only to services organizations. Project planning processes are frequently mostly performed in the construction sector. These results confirm findings quoted by other studies (e.g. Pennypacker and Grant, 2003; Ibbs and Kwak, 2000).

Production and maintenance organizations, which scored the lowest on project success, received the lowest PPI score as well (3.4). The moderate scores for software and communications organizations are not aligned with relatively poor time and cost project results. This may be due to a riskier technology and environment, poor control, or over-ambitious commitments to the customer.

After analyzing the average use of each of the 16 planning processes across the four industries, some significant differences have been found. Compared to other sectors, construction project managers excel in activity duration estimating, schedule development, quality planning, staff acquisition, and procurement planning. These results emphasize the uniqueness of construction projects. Critical project management areas in construction project planning include: (1) schedule management, due to the extremely importance of completing projects on time, (2) quality management, due to safety issues, and (3) procurement management, due to the recognized importance of this area in the construction sector (e.g. Wood and Ellis, 2005; Brown, 1996; Mustafa, 1999). 
Scope planning and cost estimating planning processes have been found to be the main weaknesses of the construction sector, in comparison to other sectors. These results may reflect relatively similar project executed in the construction sector, as compared with other sectors. This similarity among projects requires less effort dedicated to scope planning and cost estimating, if the organization keeps records of previous projects.

\section{Critical success processes for the construction sector}

This section focuses only on construction projects, in order to identify critical planning processes for this sector. In this paper, a critical planning process is a key factor that significantly improves project success. Therefore, critical processes will be identified by comparing all the impact on project success among all planning processes. The relative impact on project success of each planning process was calculated, using a multivariance regression. In this analysis, all four project success variables have been analyzed together in the same regression equation as the dependent variables. All 16 planning processes have acted as the independent variables in this analysis. The significance level was used as the measure to evaluate the importance of a planning process on project success. Table 5 ranks the impact of all 16 planning processes on project success, sorted by their importance.

\section{$<$ Table 5 >}

Table 5 introduces two critical success processes for the construction industry, which have a significant impact on project success. These critical planning processes are: "activity definition", and "project plan development". These processes include 
the core of project planning, meaning the list of project activities (which influences scope, scheduling, and cost), as well as the entire project plan document.

"Activity definition" has been found as the most important planning process in the construction sector, as it has the most significant influence on project success. This planning process requires the identification of all activities that have to be executed before project completion. Missing an activity at this stage of the project, not only reduces the performances of the new building, but also requires more time and budget to complete the missing activities close to project completion.

The second critical planning process in the construction sector is "project plan development". This finding should encourage project managers, estimators, and planners to invest more effort and thought to the development of a project plan document. Moreover, receiving comments for this document, from key stakeholders, may also increase the quality of the project plan.

\section{The focus of construction project managers in planning}

Finally, in order to integrate all findings of this study, a graph that appears in Figure 2 has been developed. The objective of this graph is to compare what construction project managers actually do, with respect to the critical planning processes identified in this paper. Figure 2 presents the 16 planning processes included in this research, each with two calculated values. The planning process' significance level (represents the impact on project success, and was measured by the significant level from the multivariance regression) appears in the $\mathrm{X}$-axis, and its extent of use (as was calculated directly from the questionnaires) appears in the $\mathrm{Y}$ axis. A regression line was calculated in order to find the relationship between those two variables. A negative relationship is expected between the two dimensions, 
representing higher use of a planning process when its significance level is lower (higher impact on project success).

\section{$<$ Figure 2 >}

The regression model described in Figure 2 has been found to be insignificant, with R squared value of 0.22 and a significant level of 0.07 . This means that project managers, planners, and estimators in the construction industry do not invest more effort in executing the most important planning processes. More specifically, some planning processes receive less attention than is expected from their impact on project success. For example, "cost estimating" and "cost budgeting" processes, have been found to be performed in a relatively low extent of use. As a result, project managers, planners, and estimators from the construction industry should pay more attention to these planning processes. By doing so, there is a greater chance of completing the project successfully. In addition, project success can be improved if project managers emphasize more on other planning processes, such as "communications planning", "risk planning", and "procurement planning".

\section{Conclusion}

The importance of project management in the construction sector has rapidly increased in the last few decades. As a result, project managers, estimators, and planners have to continuously improve their project management capabilities. Comparing 555 projects across four industries, this paper has found that organizations from the construction sector achieve high scores in project planning, as well as in project success. These results are aligned with the literature. 
This study has also identified specific critical planning processes in construction projects. "Activity definition" has been found to be the most critical planning process for the construction sector, significantly influencing project success. Hence, a construction project manager should spend more effort while identifying project activities. This can be done by using one of the tools described in the project management literature, e.g. subdividing the work breakdown structure work packages into more detailed activities (PMI, 2004). Development of a project plan has been found as another critical planning process in the construction sector. Construction project management training programs should also emphasize more on planning. Construction organizations should support their project managers with proper assistance in this area. In doing so, construction projects may achieve better results in all success dimensions.

Specific weaknesses of the construction sector have been identified in the current study. The paper suggests that some construction project managers, do not focus on the most important processes while planning projects. Specifically, more effort should be invested in the following planning processes: cost estimating, cost budgeting, communications planning, risk planning, and procurement planning. In summary, although some poor planning processes are identified in the construction industry, both the quality of project planning and project success results have been found to be very high. This paper contributes to the project management knowledge by identifying unique critical planning processes in the construction industry. This gives more practical tools to construction project managers and more understanding of construction projects to scholars. The critical planning processes introduced in this paper can be implemented by project managers, planners, and 
estimators during tenders and project planning. This paper contributes to the current body of knowledge in the following ways:

(1) It identifies the most effective planning processes in the construction industry.

(2) It makes specific recommendations to planning improvement for construction project managers, planners and estimators.

(3) It uses a focused critical planning processes approach, which allows better decision making in a project environment.

(4) It allows practitioners achieving a high quality project plan.

Finally, limitation of this study should be recognized. The research focuses only on the planning phase of the project. A further research focusing on other phases of a project should be conducted as well. The number of observations from each industry is different, but statistical analyses take this into consideration. Finally, data was collected in three countries only; hence, future research should be conducted using the same research tool in additional countries. 


\section{References}

Belle, R. A. (2002). Critical market forces and design-build. DBIA online. Available from http://www.dbia.org/pubs/ belle01.html.

Blyth, K., Lewis, J., Kaka, A. (2004). Developing a framework for a standardized works programme for building projects. Construction Innovation. 4, 4; p. 193.

Brown, A. W. (1996). A causal path model to measure project management performance in public sector capital building projects in Scotland, $\mathrm{PhD}$ thesis, Napier University, October.

Brown, A., Hinks, J. and Sneddon, J. (2001). The facilities management role in new building procurement. Facilities. Bradford: Mar/Apr. 9, 3/4; p. 119.

Chen, C. and Messner, J. I. (2005). An investigation of Chinese BOT projects in water supply: a comparative perspective. Construction Management and Economics, 23, 9; p. 913.

Cooke-Davies, T. J. \& Arzymanow, A. (2002). The Maturity of Project Management in Different Industries: An Investigation into Variations between Project Management models. International Journal of Project Management, 21, p. 471-478.

Crawford, L., Pollack, J., England, D. 2006. Uncovering the trends in project management: Journal emphases over the last 10 years. International Journal of Project Management, 24, 2, p. 175.

Faniran, O. O., Oluwoye, J. O. and Lenard, D. J. (1998). Interactions between construction planning and influence factors. Journal of Construction Engineering and Management, 124, 4, p. 245-256.

Garmezy, N., Harlow, H. F., Jones, L. V. \& Stevenson, H. W. (1967). Principles of general psychology. New York, Ronald Press Co. 
Globerson, S. \& Zwikael, O. (2002). Impact of the Project Manager on Project Management Planning Processes. Project Management Journal, 33, 3, p. 58-64.

Hair, J. F. (2006). Marketing research. McGraw-Hill, New York.

Heesom, D., Mahdjoubi, L. (2004). Trends of 4D CAD applications for construction planning. Construction Management and Economics, 22, 2; p. 171.

Hughes, S. W., Tippett, D. D. and Thomas, W. K. (2004). Measuring Project Success in the Construction Industry. Engineering Management Journal, 16, 3; p. 3137.

Ibbs, C. W. \& Kwak, Y. H. (2000). Assessing Project Management Maturity. Project Management Journal, 31, 1, p. 32-43.

Johnson, J., Karen, D., Boucher, K. C. \& Robinson, J. (2001). Collaborating on Project Success. Software Magazine, February/March.

Kadefors, A. (2005). Fairness in interorganizational project relations: norms and strategies. Construction Management and Economics. 23, 8; p. 871.

Kerzner, H. (2006). Project Management: A Systems Approach to Planning, Scheduling and Controlling. 9th edition, John Wiley and Sons.

Leung, M. Y., Ng, T. S., Skitmore, M., Cheung, S. O. (2005). Critical stressors influencing construction estimators in Hong Kong. Construction Management and Economics, 23, 1; p. 33.

Leung, M. Y., Ng, S. T. \& Cheung, S. O. (2004). Measuring construction project participant satisfaction. Construction Management and Economics, 22, 3; p. 319.

Malik, M. A. K., McDermott, P. \& Swan, W. (2007). Building trust in construction projects. Supply Chain Management, 12, 6, p. 385-391.

Meredith J. R. and Mantel S. J. (2006). Project Management - A Managerial Approach. (6th Ed.) John Wiley and Sons. 
Mustafa, A. (1999). Public-private partnership: an alternative institutional model for implementing the private finance initiative in the provision of transport infrastructure. Journal of Private Finance, 5, 2, p. 64-79.

Paulk, M. C., Curtis, B., Chrissis, M. B. and Weber, C. V. (1995). The Capability Maturity Model for Software, Software Engineering Institute, Carnegie Mellon University, Pittsburg, PA, USA.

Pennypacker, J. S. \& Grant, K. P. (2003). Project Management Maturity: An Industry Benchmark. Project Management Journal, March, p. 4-9.

Petersen, D. R. and Murphree, E. L. (2004). The impact of owner representatives in a design-build construction environment. Project Management Journal, 35, 3; p. 27-38. Pinto, J. K. \& Slevin, D. P. (1989). Critical Success Factors in R\&D Projects. Research Technology Management. January-February, p. 31-35.

PMI Standards Committee. (2000). A Guide to the Project Management Body of Knowledge. Newtown Square, PA: Project Management Institute.

PMI Standards Committee. (2004). A Guide to the Project Management Body of Knowledge. Newtown Square, PA: Project Management Institute.

Robinson, H. S., Carrillo, P. M., Anumba, C. J. \& Al-Ghassani, A. M. (2005). Review and implementation of performance management models in construction engineering organizations. Construction Innovation. 5, 4, p. 203-217.

Russell, R. S. \& Taylor, B. W. (2003). Operations Management. 4th Ed. Pearson Education, New Jersey.

Sarshar, M., Haigh, R. \& Amaratunga, D. (2004). Improving project processes: best practice case study. Construction Innovation, 4, 2, p. 69-82. 
Shenhar, A., Dvir, D., Milosevic, D., Mulenburg, J. (2005). Toward a NASA-

Specific Project Management Framework. Engineering Management Journal, 17, 4; p. $8-16$.

Silk, M. A. and Black, S. (1999). Back to the drawing board. Project Finance, 197, p. 38-9.

Tam, C. M., Tong, T. K. L. (2005). Multiple GMDH models for estimating resource requirements. Construction Innovation, 5, 2; p. 115.

Turner, J. R. (1999). The handbook of project-based management: Improving the processes for achieving strategic objectives. London: McGraw-Hill.

Winch, G. M., Kelsey, J. (2005). What do construction project planners do? International Journal of Project Management, 23, 2; p. 141.

Wood, G. D. \& Ellis, R. C. T. (2005). Main Contractor experiences of partnering relationships on UK construction projects. Construction Management and Economics, 23, 3; p. 317.

World Bank (1996). Survey of International Construction Projects, World Bank. Zwikael, O. \& Globerson, S. (2004). Evaluating the Extent of Use of Project Planning: A Model and Field Results. International Journal of Production Research, 42,8, p. $1545-1556$.

Zwikael, O., Shimizu, K. \& Globerson, S. (2005). Cultural Differences in Project Management Processes: A Field Study. International Journal of Project Management, 23,6, p. $454-462$.

Zwikael, O. \& Globerson, S. (2006). From Critical Success Factors to Critical Success Processes. International Journal of Production Research, 44, 17, p. 3433 3449. 
Zwikael, O., Sadeh, A. (2007). Planning effort as an effective risk management tool.

Journal of Operations Management, 25, 4, p. 755-767.

Zwikael, O. (2008). Top management involvement in project management exclusive support practices for different project scenarios. International Journal of Managing Projects in Business, 1, 3. 
16 Planning Processes

1. Project plan development

1. Schedule overrun

2. Scope planning

2. Cost overrun

3. Scope definition

3. Project performance

4. Activity definition

4. Customer satisfaction

5. Activity sequencing

6. Activity duration estimating

7. Schedule development

8. Resource planning

9. Cost estimating

10. Cost budgeting

11. Quality planning

12. Organizational planning

13. Staff acquisition

14. Communications planning

15. Risk management planning

16. Procurement planning

Figure 1 - The research model 


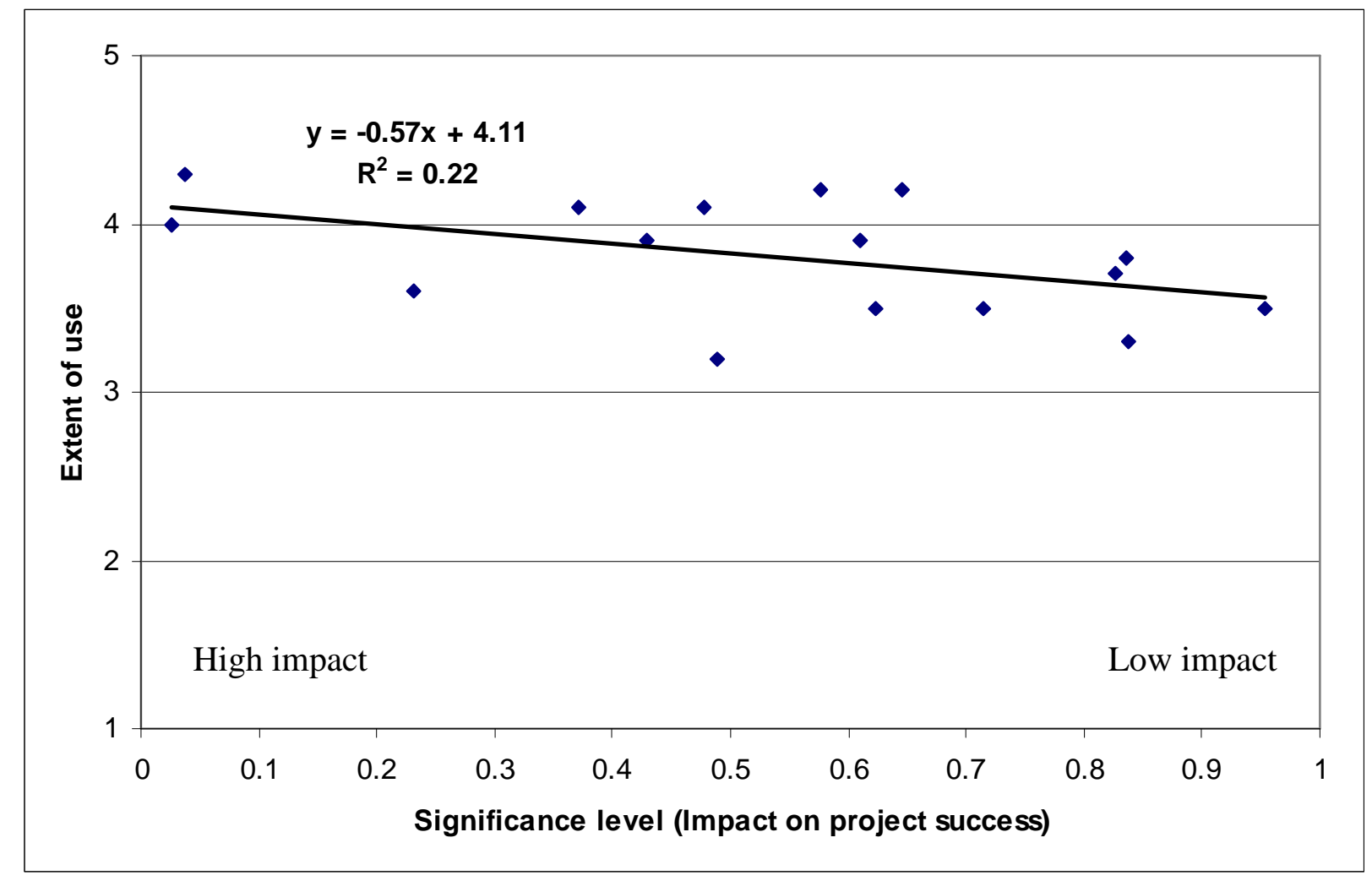

Figure 2 - The extent of use of planning processes vs. their impact on project success in construction organizations 


\begin{tabular}{|l|c|c|c|c|}
\hline \multicolumn{1}{|c|}{ Industry Type } & CO & SC & SE & PM \\
\hline $\begin{array}{l}\text { Total number of } \\
\text { questionnaires }\end{array}$ & $\mathbf{1 4 4}$ & 425 & 91 & 93 \\
\hline $\begin{array}{l}\text { Number of valid } \\
\text { questionnaires }\end{array}$ & $\mathbf{1 1 5}$ & 319 & 58 & 63 \\
\hline $\begin{array}{l}\text { Percentage of valid } \\
\text { questionnaires }\end{array}$ & $\mathbf{8 0 \%}$ & $75 \%$ & $64 \%$ & $68 \%$ \\
\hline $\begin{array}{l}\text { Number of valid } \\
\text { questionnaires - Israel }\end{array}$ & $\mathbf{4 9}$ & 132 & 10 & 15 \\
\hline $\begin{array}{l}\text { Number of valid } \\
\text { questionnaires - Japan }\end{array}$ & $\mathbf{1}$ & 79 & 10 & 33 \\
\hline $\begin{array}{l}\text { Number of valid } \\
\text { questionnaires - New } \\
\text { Zealand }\end{array}$ & $\mathbf{6 0}$ & 103 & 31 & 15 \\
\hline
\end{tabular}

Table 1: Number of questionnaires from each industrial sector in the research sample

The following abbreviations were used in Table 1:

$\mathrm{CO}$ - Construction

SE - Services

SC - Software \& Communications

PM - Production \& Maintenance 


\begin{tabular}{|l|r|r|}
\hline \multicolumn{1}{|c|}{ Success Measure Equation } & R & p-value \\
\hline Schedule Overrun $=\mathbf{5 3 \%}-\mathbf{1 0 \%} *$ PPI & 0.32 & $<\mathbf{0 . 0 0 1}$ \\
\hline Cost Overrun = 47\% - 9\% * PPI & 0.29 & $<\mathbf{0 . 0 0 1}$ \\
\hline Project performance $=\mathbf{4 . 9 4}+\mathbf{0 . 7 5} *$ PPI & 0.30 & $<\mathbf{0 . 0 0 1}$ \\
\hline Customer Satisfaction $=\mathbf{5 . 4 6}+\mathbf{0 . 6 7} *$ PPI & 0.33 & $<\mathbf{0 . 0 0 1}$ \\
\hline
\end{tabular}

Table 2 - Validity tests for the PMPQ model

* PPI level ranges 1 to 5 , where 5 is the best level of planning and 1 is the poorest level. 


\begin{tabular}{|l|c|c|c|c|}
\hline \multicolumn{1}{|c|}{ Industry Type } & CO & SC & SE & PM \\
\hline $\begin{array}{l}\text { Schedule Overrun } \\
(\boldsymbol{\%})\end{array}$ & $\mathbf{1 2 \%}$ & $19 \%$ & $13 \%$ & $22 \%$ \\
\hline $\begin{array}{l}\text { Cost Overrun } \\
(\boldsymbol{\%})\end{array}$ & $\mathbf{1 2 \%}$ & $15 \%$ & $13 \%$ & $16 \%$ \\
\hline $\begin{array}{l}\text { Project performance } \\
(\mathbf{1 - 1 0} \text { scale) }\end{array}$ & $\mathbf{8 . 4}$ & 7.3 & 7.9 & 7.0 \\
\hline $\begin{array}{l}\text { Customer Satisfaction } \\
(\mathbf{1 - 1 0} \text { scale) }\end{array}$ & $\mathbf{8 . 3}$ & 7.8 & 7.7 & 7.2 \\
\hline
\end{tabular}

Table 3: Project success measures in different sectors

The following abbreviations were used in Table 3:

$\mathrm{CO}$ - Construction

SE - Services

SC - Software \& Communications

PM - Production \& Maintenance 


\begin{tabular}{|l|c|c|c|c|}
\hline \multicolumn{1}{|c|}{ Industry Type } & CO & SC & SE & PM \\
\hline Planning Processes & & & & \\
\hline Project plan development & $\mathbf{4 . 3}$ & 4.0 & 4.5 & 3.7 \\
\hline Scope planning & $\mathbf{4 . 1}$ & 4.2 & 4.5 & 4.1 \\
\hline Scope definition & $\mathbf{3 . 7}$ & 3.7 & 4.2 & 3.3 \\
\hline Activity definition & $\mathbf{4 . 0}$ & 4.1 & 4.5 & 3.6 \\
\hline Activity sequencing & $\mathbf{4 . 1}$ & 3.7 & 4.2 & 3.7 \\
\hline Activity duration estimating & $\mathbf{4 . 2}$ & 4.2 & 4.1 & 3.9 \\
\hline Schedule development & $\mathbf{4 . 2}$ & 4.2 & 4.2 & 3.9 \\
\hline Resource planning & $\mathbf{3 . 8}$ & 3.9 & 3.8 & 3.5 \\
\hline Cost estimating & $\mathbf{3 . 5}$ & 3.7 & 3.7 & 3.5 \\
\hline Cost budgeting & $\mathbf{3 . 6}$ & 3.4 & 3.8 & 2.7 \\
\hline Quality planning & $\mathbf{3 . 5}$ & 3.0 & 3.2 & 2.7 \\
\hline Organizational planning & $\mathbf{3 . 9}$ & 3.9 & 3.9 & 3.9 \\
\hline Staff acquisition & $\mathbf{3 . 9}$ & 3.7 & 3.8 & 3.5 \\
\hline Communications planning & $\mathbf{3 . 2}$ & 2.9 & 3.5 & 2.8 \\
\hline Risk management planning & $\mathbf{3 . 5}$ & 3.2 & 3.7 & 3.1 \\
\hline Procurement planning & $\mathbf{3 . 3}$ & 2.8 & 3.1 & 2.8 \\
\hline Overall PPI & $\mathbf{3 . 8}$ & $\mathbf{3 . 7}$ & $\mathbf{3 . 9}$ & $\mathbf{3 . 4}$ \\
\hline
\end{tabular}

Table 4: Extent of use of planning processes by industries (1=low, 5=high)

The following abbreviations were used in Table 4:

$\mathrm{CO}$ - Construction

SC - Software \& Communications

SE - Services

PM - Production \& Maintenance 


\begin{tabular}{|l|l|}
\hline \multicolumn{1}{|c|}{ Planning Process } & \multicolumn{1}{c|}{$\begin{array}{c}\text { Impact on Project Success } \\
\text { (significance Level) }\end{array}$} \\
\hline Activity definition & $0.027^{*}$ \\
\hline Project plan development & $0.038^{*}$ \\
\hline Cost budgeting & 0.231 \\
\hline Scope planning & 0.372 \\
\hline Organizational planning & 0.429 \\
\hline Activity sequencing & 0.478 \\
\hline Communications planning & 0.489 \\
\hline Schedule development & 0.576 \\
\hline Staff acquisition & 0.611 \\
\hline Risk management planning & 0.624 \\
\hline Activity duration estimating & 0.646 \\
\hline Cost estimating & 0.715 \\
\hline Scope definition & 0.827 \\
\hline Resource planning & 0.835 \\
\hline Procurement planning & 0.837 \\
\hline Quality planning & 0.953 \\
\hline
\end{tabular}

Table 5 - Impact of planning processes on project success in construction organizations

$* p \leq 0.05 ; * * p \leq 0.01$ 


\section{Appendix A - The study's questionnaires}

\section{The project manager's questionnaire:}

Please indicate the most suitable answer for each planning product as it relates to the projects you are currently involved in, according to the following scale:

5 - The product is always obtained.

4 - $\quad$ The product is quite frequently obtained.

3 - The product is frequently obtained.

2 - $\quad$ The product is seldom obtained.

1 - The product is hardly ever obtained.

A - The product is irrelevant to the projects I am currently involved in.

B - I do not know whether the product is obtained.

\begin{tabular}{|c|c|c|c|c|c|c|c|}
\hline Planning Product & \multicolumn{3}{|c|}{ Never } & \multicolumn{2}{|c|}{ Always } & 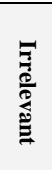 & 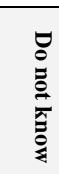 \\
\hline 1. Project Plan & 1 & 2 & 3 & 4 & 5 & A & B \\
\hline 2. Project Deliverables & 1 & 2 & 3 & 4 & 5 & $\mathrm{~A}$ & B \\
\hline 3. WBS (Work Breakdown Structure) Chart & 1 & 2 & 3 & 4 & 5 & $\mathrm{~A}$ & B \\
\hline 4. Project Activities & 1 & 2 & 3 & 4 & 5 & A & B \\
\hline 5. PERT or Gantt Chart & 1 & 2 & 3 & 4 & 5 & $\mathrm{~A}$ & B \\
\hline 6. Activity Duration Estimate & 1 & 2 & 3 & 4 & 5 & A & B \\
\hline 7. Activity Start and End Dates & 1 & 2 & 3 & 4 & 5 & A & B \\
\hline 8. Activity Required Resources & 1 & 2 & 3 & 4 & 5 & A & B \\
\hline 9. Resource Cost & 1 & 2 & 3 & 4 & 5 & $\mathrm{~A}$ & B \\
\hline 10. Time-phased Budget & 1 & 2 & 3 & 4 & 5 & $\mathrm{~A}$ & B \\
\hline 11. Quality Management Plan & 1 & 2 & 3 & 4 & 5 & $\mathrm{~A}$ & B \\
\hline 12. Role and Responsibility Assignments & 1 & 2 & 3 & 4 & 5 & $\mathrm{~A}$ & B \\
\hline 13. Project Staff Assignments & 1 & 2 & 3 & 4 & 5 & $\mathrm{~A}$ & B \\
\hline 14. Communications Management Plan & 1 & 2 & 3 & 4 & 5 & $\mathrm{~A}$ & B \\
\hline 15. Risk Management Plan & 1 & 2 & 3 & 4 & 5 & A & B \\
\hline 16. Procurement Management Plan & 1 & 2 & 3 & 4 & 5 & A & B \\
\hline
\end{tabular}




\section{The supervisor's questionnaire:}

1. Average time overrun at end of projects in comparison with the original planned schedule approved by customer: $\%$

2. Average budget overrun at end of projects in comparison with the budget approved by customer: $\%$

Please evaluate the following factors on a 1-10 scale (1=low, 5-6=middle, 10=high):

\begin{tabular}{|l|c|c|c|c|c|c|c|c|c|c|}
\hline & \multicolumn{1}{|l}{ Low } & \multicolumn{4}{c|}{ Medium } & $\mathbf{9}$ & $\mathbf{9}$ \\
\hline $\begin{array}{l}\text { (3) The extent to which project } \\
\text { objectives were obtained in } \\
\text { comparison to the customer's } \\
\text { approved plans }\end{array}$ & $\mathbf{1}$ & $\mathbf{2}$ & $\mathbf{3}$ & $\mathbf{4}$ & $\mathbf{5}$ & $\mathbf{6}$ & $\mathbf{7}$ & $\mathbf{8}$ & $\mathbf{9}$ & $\mathbf{1 0}$ \\
\hline $\begin{array}{l}\text { (4) The average customer's } \\
\text { satisfaction level at the end of } \\
\text { the project }\end{array}$ & $\mathbf{1}$ & $\mathbf{2}$ & $\mathbf{3}$ & $\mathbf{4}$ & $\mathbf{5}$ & $\mathbf{6}$ & $\mathbf{7}$ & $\mathbf{8}$ & $\mathbf{9}$ & $\mathbf{1 0}$ \\
\hline
\end{tabular}

